\title{
THE LIFE QUALITY OF ELDERLY PEOPLE AS A SOCIAL AND ECONOMIC PROBLEM
}

\section{Streszczenie}

W artykule przedstawiono koncepcje ,jakości życia osób starszych” jako kategorii złożonej, przeanalizowano kluczowe wytyczne dotyczace jakości życia osób starszych oraz określono jej obiektywne i subiektywne wskaźniki.

Słowa kluczowe: jakość życia, osoby starsze, jakość życia osób starszych; obiektywna i subiektywna jakość życia.

\section{Introduction}

The quality of people's life is a strategic priority of the state development now. Special attention is paid to the quality of life of socially vulnerable categories of the population, including elderly people. According to the classification of World Health Organization persons aged from 60 to 74 are classified as the elderly, from 75 to 89 - as old, those aged 90 and over are called centenarians. Some American experts suggest another classification, which distinguish older people as ,young elderly" - 65-74 years, old - aged 75-84 and very old - 85 and older. In Ukraine, the definition of ,an elderly person” often means a person who has reached his/ her retirement age ${ }^{261}$.

* Zaryna Atamanchuk - Ph.D. in economic sciences, Associate Professor in Accounting and Finance Department of Lviv Institute Economics and Tourism, Lviv.

1 Сагач Я. С. Методологічні проблеми дослідження рівня життя людей похилого віку / Я. С. Сагач [Електронний ресурс]. - Режим доступу: http://bit.ly/snrl8-3-15. (11.12.2016r). 
Issues of life quality are highlighted in scientific studies of Yermak N. A, Kabanova A. A, Zhytynskya M. O. ${ }^{2}$, Levada O. A. ${ }^{3}$, Sahach Ya. S, Cherkas N. I. ${ }^{4}$, Uzunova F. V., Shvets I. B. and others. Among foreign researchers who study the quality of life of separate individuals and a society, a special place of take the works of Jo. Gelbraith, A. Campbell, James. Keynes, Maslow, David Foster, C. Rogers and others.

The quality of life in the economic literature is defined as a complex category, which allows the enjoyment of cultural, material, spiritual and other human needs through their own subjective self-assessment of his/her life and professionals' measurement by a fixed set of objective indicators ${ }^{5}$. A key reference point for interpretation of the quality of life of elderly people are economic factors as they determine the economic potential of the country, economic development of society, the size of pension and affect the welfare of citizens; social factors, characterized by the development of social infrastructure, the degree of satisfaction of social needs of elderly people and their social security; political and legal factors that mean following human rights of elderly people and affect the level and quality of their life through the governmental work, social organizations, laws; environmental factors that determine health, food stuffs' quality, environmental state; cultural factors that affect their spiritual and intellectual development as well as spiritual values.

\section{Economic factors as an important reference point for interpretation the quality life of elderly people}

The world is aging fast. By 2030, there will have been more people over 60 than under the age of 10. According to the «Global Age Watch Index» rating, compiled with the support of UNO Fund in the field of population and is dedicated to the situation of pensioners in 91country, Ukraine takes 66th position on the

2 Житинська М. О. Життєдіяльність людей похилого віку в Україні: реалії та перспективи / М. О. Житинська // Молодий вчений. -2015. - № 2 (17). - лютий. - С. 245-248.

3 Пінчук І. Я. Актуальні питання геронтопсихіатрії: навчальний посібник / І. Я. Пінчук, В. В. Чайковська, О. А. Левада, М. М. Пустовойт, М. І. Ширяєва. Тернопіль: ТзОВ «Терно-граф», 2010. - 432 с.

4 Атаманчук 3. А. Вплив макроекономічної політики та політичного циклу на формування нерівності доходів в Україні / Н. І. Черкас, 3. А. Атаманчук // Вплив політичних циклів на якість життя та рівень щастя в Україні: матеріали засідання круглого столу, 29 березня. - Львів : ЛКА, 2013. - С. 111-115.

Житинська М. О. Забезпечення якості життя людей похилого віку як соціальна проблема / О. М. Житинська // Освітологічний дискурс. - 2015. - № 1 (9). - С. 116-124. 
list of countries, in which the level of life of elderly people was assessed, right after South Africa. By the rating the elderly are the people aged 60 and over. The level of their life was tested in 91 country. The quality of life was determined by four factors: opportunities of job and education, level of economic security, availability of favorable environment for life and health. The greatest achievement of Ukraine in this rating concerns the level of education and the number of working pensioners $-35^{\text {th }}$ place. The $77^{\text {th }}$ place was given to Ukrainians by the state of health of elderly people. $86^{\text {th }}$ rating line goes to Ukraine for the availability of a favorable environment for life. Ukraine takes $39^{\text {th }}$ position in its economic security, that is to say, the financial welfare of Ukraine. The first three places in this rating concerning the quality of life of people over the age of 60 were given to Sweden 1 st place, Norway $-2^{\text {nd }}$ place and Germany $-3^{\text {rd }}$ place. The top ten countries are the Netherlands, Canada, Switzerland, New Zealand, the USA, Iceland and Japan. Among the countries of the former USSR the leader is Estonia ( $29^{\text {th }}$ place). Belarus took the $60^{\text {th }}$ place, and Russia $-78^{\text {th }} 6$.

In the system which determines the level of people's life central positions go to the indicators, which show a main source of personal needs' satisfaction in goods and services and raising of their welfare level. Level of income gives an idea about the financial capabilities of people, especially when this level is rather low. In Ukraine, a sharp differentiation of the population by their level of income is observed, which has negative consequences both for working people and the elderly, because the pension is their main source of income. Because of the low pension the majority of pensioners were below the poverty line. People who have reached their retirement age and made their labour contribution to the development of the country, are unable to live with dignity and relax. The standard of living of the population is at unacceptably low level.

The average pension in Ukraine in February 2015 was 65 US dollars, it's 2,7 times lower in comparison with the previous year (Fig. 1). At the same time the pension of a Pole is 7,4 times higher than the pension of Ukrainian person and the pension of an American is almost 18 times higher than that of the Ukrainian.

Thus most of the income of the average Ukrainian, is directed exclusively to buy foodstuffs, while in the UK, Germany and other industrialized countries, the figure barely reaches $10 \%$ mark $^{317}$.

6 HelpAge International [Електронний pecypc]. - Режим доступу: http://www. helpage.org. (11.12.2016r).

7 Eurostat: Official EU statistical data [Електронний ресурс]. - Режим доступу: http://www.eui.eu/Research/Library (11.12.2016r). 


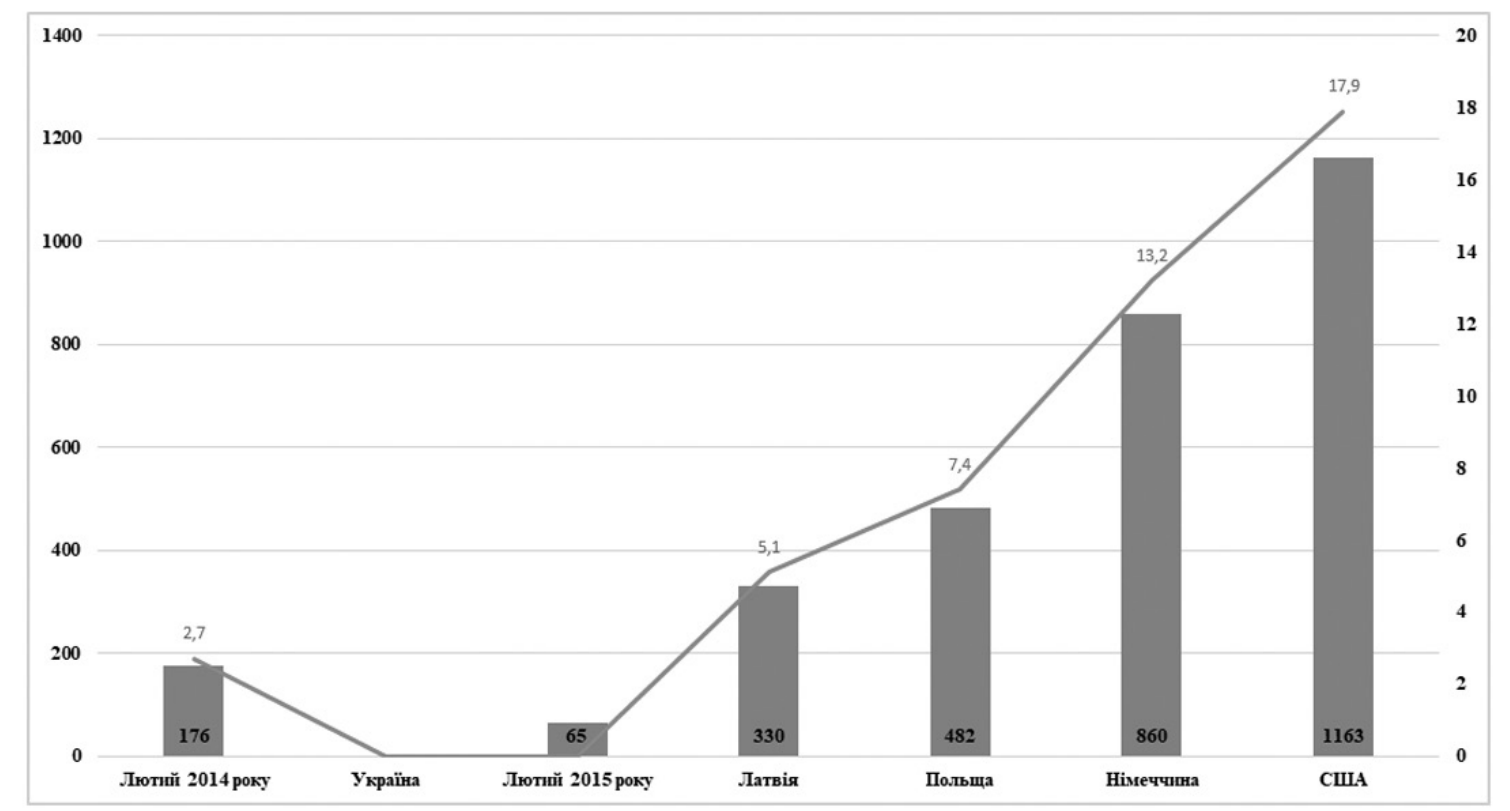

Fig. 1. The average pension in Ukraine and other countries of the world (by the rate National Bank of Ukraine (NBU) in the corresponding period), \$ (Source is developed by Eurostat. Official EU statistical data) Source is developed by Eurostat. Official EU statistical data

\section{The population aging impact on quality of life}

According to the report of the World Health Organization published before the International Day of elderly people (1 October), it is expected that by 2050 the number of people over 60 will double, and this in turn requires fundamental strict social changes. In Ukraine, as in the whole world, a tendency of population aging is observed: percentage share of the population over 60 is over $20 \%$ mark.

According to the scale of demographic aging by God-Jean Garnier and E. Rosset Ukraine can be attributed to the countries that are at the stage of "demographic aging". In the majority of post-Soviet countries level of birth is consistently decreasing, length of people's life does not grow, mortality in the older age is almost not reduced. By 2040 in the European Union countries, $28 \%$ of the population will have been represented by people aged 65 and over. Even China, Brazil and India are rapidly approaching the mark of $20 \%$ of elderly people of total population (Fig. 2). 


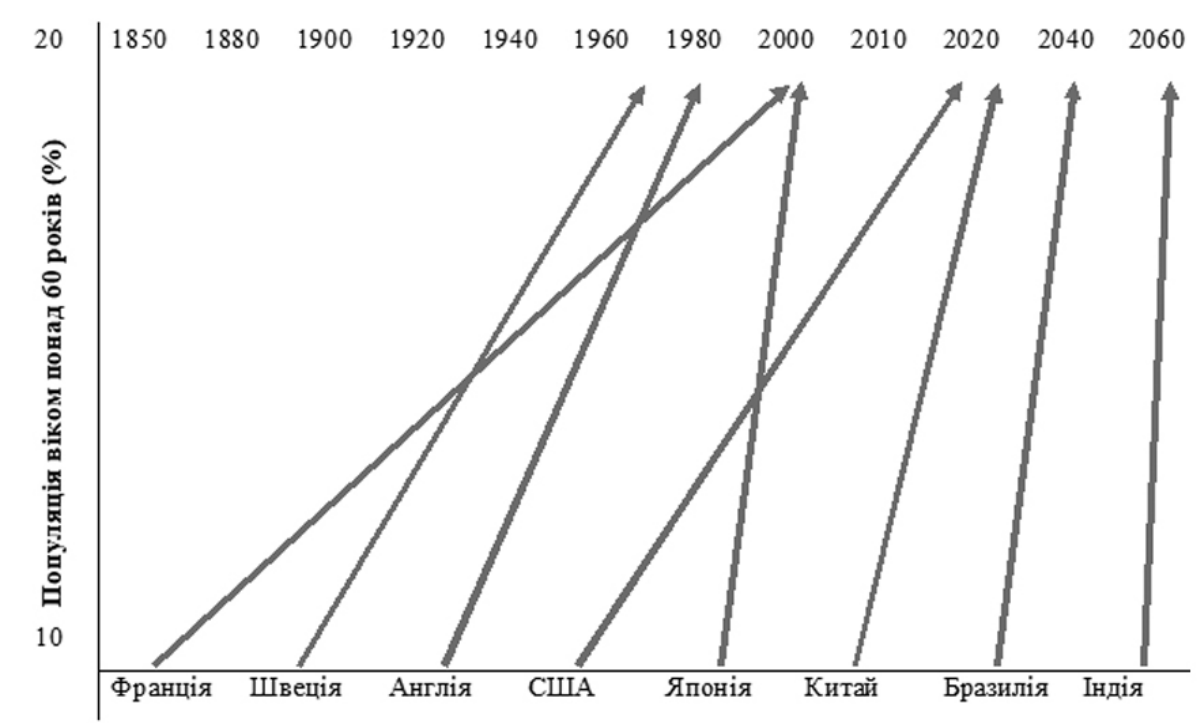

Fig. 2. The period required for the growth of percentage of the population aged 60 and over from $10 \%$ to $20 \%$

With the growth of the average age of the population (which is classified as elderly and old) more and more people will suffer from chronic illness (somatic and mental) and disabilities due to the oncological diseases, cardiovascular diseases, fractures, dementia, etc. In addition, a growing number of people will be influenced simultaneously by several pathological states. The presence of multiple diseases in each patient and their progredience largely depends on genetic predisposition. External pathogenic factors are primarily recurrent acute or chronic stresses.

Early aging and death of middle-aged have become an urgent problem of the society. Although somehow elderly people do not have much social and family influence, but the body is aging and many health problems that were accumulated earlier, are being diagnosed worsening the quality of people's life. According to the data of World Health Organization, every middle-aged and elderly person has at least four officially recorded diseases ${ }^{9}$.

8 Чабан О. С. Психосоматична коморбідність і якість життя у пацієнтів похилого віку / О. С. Чабан, О. О. Хаустова // [Електронний ресурс]. - Режим доступу : http:// neuronews.com.ua/page/psihosomatichna-komorbidnist-i-yakist-zhittya-u-pacientiv-pohilogo-viku] (12.01.2017r).

9 Всесвітня організація охорони здоров'я [Електронний ресурс]. - Режим доступу: http://bit.ly/snrl8-3-16 


\section{Conclusion}

System of components of the level and quality of elderly people's life is very diverse, because it involves such factors as economic, social, political and legal, environmental and cultural and has got a specific character. The provision of welfare, social and moral health of an elderly person is a fundamental duty of any state. At present stage of social relations humanization new, independent areas of social aid, maintenance and support of elderly people are being determined. The change of emphasis on the reproduction of adaptive and rehabilitative potential of elderly people requires the implementation of effective innovative technologies that would really affect the existing problems and improve the quality of life of the researched category of population in the state.

\section{Bibliografia}

Сагач Я. С. Методологічні проблеми дослідження рівня життя людей похилого віку Я. С. Сагач [Електронний ресурс]. - Режим доступу: http://intkonf.org/ sagach-yas-metodologichni-problemi-doslidzhennya-rivnya-zhittya-lyudey-pohilogo-viku/. (11.12.2016r).

Житинська М. О. Життєдіяльність людей похилого віку в Україні: реалії та перспективи / М. О. Житинська // Молодий вчений. - 2015. - № 2 (17). лютий. - С. 245-248.

Пінчук І. Я. Актуальні питання геронтопсихіатрії: навчальний посібник / І. Я. Пінчук, В. В. Чайковська, О. А. Левада, М. М. Пустовойт, М. І. Ширясва. - Тернопіль : ТзОВ «Терно-граф», 2010. - 432 с.

Атаманчук 3. А. Вплив макроекономічної політики та політичного циклу на формування нерівності доходів в Україні / Н. І. Черкас, 3. А. Атаманчук // Вплив політичних циклів на якість життя та рівень щастя в Україні: матеріали засідання круглого столу, 29 березня. - Львів : ЛКА, 2013. - C. 111-115.

Житинська М. О. Забезпечення якості життя людей похилого віку як соціальна проблема / О. М. Житинська // Освітологічний дискурс. - 2015. - № 1 (9). - C. 116-124.

HelpAge International [Електронний pecypc]. - Режим доступу: http://www. helpage.org/.

Eurostat: Official EU statistical data [Електронний ресурс]. - Режим доступу: http://www.eui.eu/Research/Library/.(11.12.2016r).

Чабан О. С. Психосоматична коморбідність і якість життя у пацієнтів похилого віку / О. С. Чабан, О. О. Хаустова // [Електронний ресурс]. 
- Режим доступу: http://neuronews.com.ua/page/psihosomatichna-komorbidnist-i-yakist-zhittya-u-pacientiv-pohilogo-viku]. (12.01.2017r).

Всесвітня організація охорони здоров'я [Електронний ресурс]. - Режим доступу :https://unaids.org.ua/ua/about-unaids/diyalnist-v-ukrajini/vsesvitnia -orhanizatsiia-okhorony-zdoro(12.01.2017r).

\section{Zaryna Atamanchuk: The life quality of elderly people as a social and economic problem}

\section{Summary}

The article presents the concept of "life quality of elderly" as a complex category, analyzed key guidelines for life quality treatment of elderly and defined its objective and subjective indicators.

Keywords: life quality, elderly, life quality of the elderly people; objective and subjective quality of life. 